Article

\title{
Environmental Transformation and the Current State of Hydrogeological Condition in the Wojkowice Area-Southern Poland
}

\author{
Jacek Różkowski ${ }^{1}$, Oimahmad Rahmonov ${ }^{1, *}$, Roksana Zarychta ${ }^{2}$, and Adrian Zarychta ${ }^{3}$ (]) \\ 1 Institute of Earth Sciences, Faculty of Natural Sciences, University of Silesia in Katowice, \\ 41-200 Sosnowiec, Poland; jacek.rozkowski@us.edu.pl \\ 2 Institute of Geography, Faculty of Exact and Natural Sciences, Pedagogical University of Krakow, \\ Podchorążych 2, 30-084 Kraków, Poland; roksana.zarychta@up.krakow.pl \\ 3 Institute of Biology, Biotechnology and Environmental Protection, Faculty of Natural Sciences, \\ University of Silesia, Jagiellońska 28, 40-032 Katowice, Poland; adrian.zarychta@us.edu.pl \\ * Correspondence: oimahmad.rahmonov@us.edu.pl
}

check for updates

Citation: Różkowski, J.; Rahmonov, O.; Zarychta, R.; Zarychta, A. Environmental Transformation and the Current State of Hydrogeological Condition in the Wojkowice Area-Southern Poland. Resources 2021, 10, 54. https://doi.org/ $10.3390 /$ resources 10050054

Academic Editor:

Nicoletta Santangelo

Received: 17 March 2021

Accepted: 17 May 2021

Published: 20 May 2021

Publisher's Note: MDPI stays neutral with regard to jurisdictional claims in published maps and institutional affiliations.

Copyright: (c) 2021 by the authors. Licensee MDPI, Basel, Switzerland. This article is an open access article distributed under the terms and conditions of the Creative Commons Attribution (CC BY) license (https:/ / creativecommons.org/licenses/by/ $4.0 /)$.

\begin{abstract}
Based on the analysis and interpretation of maps, remote sensing data published in the literature, and environmental reconnaissance, this article discusses environmental transformations in the Wojkowice area in southern Poland (up to the year 2020). A comprehensive analysis was carried out concerning spatial development, mining activity, hydrogeological conditions and the biotic environment. The current state of the hydrogeological conditions was also characterized. Mining activity in the vicinity of the studied town caused significant changes in its relief, which contributed to its area dropping by about $5 \mathrm{~m}$. In fact, these terrain forms are overgrown by various forms of vegetation that colonized these areas both naturally and as a result of forest reclamation. The contemporary vegetation of Wojkowice differs from the potential natural vegetation, which is an indicator of the complete anthropogenization of the natural environment. Over 100 years of industrial activity in Wojkowice has also contributed to a strong transformation of the groundwater. There has been a quantitative depletion of usable groundwater in the Triassic and Carboniferous formations. With inflows to the ore mines of up to $17 \mathrm{~m}^{3} / \mathrm{min}$, the groundwater table has dropped by more than $60 \mathrm{~m}$. The aquifer of Muschelkalk has been practically drained. At present, wells extract the waters from the Röth aquifer. There has been a major transformation of groundwater chemistry. The waters of the Triassic carbonate complex are anthropogenically transformated and are characterized by increased mineralization, multi-ionic types and usually with a quality class III and IV, and, therefore, they require some treatment.
\end{abstract}

Keywords: landscape transformations; relief transformations; hydrogeological conditions; vegetation transformations; Wojkowice; Poland

\section{Introduction}

One of the key problems in the field of spatial management and environmental protection is the degradation of land surfaces as a result of mining activity using underground and opencast mining methods. Consequently, brownfield sites account for a significant percentage of the land use structure [1-4]. A post-industrial area is a degraded, unused or partially used area originally intended for economic activity [5-7], where industrial production took place. More broadly interpreted definitions include post-industrial areas of services provided to industry and areas of its impact [8,9].

Characteristic remnants of mining activity include underground workings, surface deformations and waste tips, as well as objects of technical and constructional infrastructure of mines and pits [10-19]. All these elements determine the beauty of the landscape and how perceptible it is to society. 
The development of mining in Europe occurred mainly in industrial centers such as the Ruhr Basin in Germany [20], Donets Basin in the Ukraine [21] and the Upper Silesian Industrial Region (Polish abbreviation: GOP) in Poland [22]. The concentration of postmining objects in GOP is so large that post-extraction regions developed there. Such regions show large-scale transformations which, according to Bartkowski [23], should be treated as contaminations and disturbances in the lithospheric component of the natural environment on the one hand, and as showing large development potential (good spatial conditions and cultural and natural values) on the other. One of the towns located in such areas is Wojkowice, which borders Czeladź, Sosnowiec, Siemianowice Śląskie and Będzin. Wojkowice belongs to the group of towns and districts located in the central part of GOP which are considerably burdened by mining activity [24].

In degraded, post-industrial and post-mining areas, for several decades without development or remediation, a process of spontaneous plant succession has been taking place. Regeneration of vegetation in such areas has become the subject of research by naturalists around the world [25-33] representing different aspects of vegetation functions in habitats disturbed by human impact [34]. Although anthropogenically transformed areas do not create a favorable habitat, increased biodiversity [35,36] can be observed in these areas, indirectly indicating their regeneration.

This work aims to present the transformation of natural environments in the mining town of Wojkowicie (southern Poland) taking into account the changes of relief, contemporary vegetation, and the chemical transformation of groundwater due to opencast and underground mining.

\section{Study Area Characteristics}

The town of Wojkowice is located in southern Poland, in the Silesian Province, in the Upper Silesian Industrial Region (GOP), within the Silesian-Krakow Upland. Wojkowice is situated to the north and west of the Bobrowniki commune, to the north-east of the Psary commune, to the south of the Piekary Ślaskie and Siemianowice Ślaskie communes, and to the east of the Będzin commune (Figure 1). The area of the town is $12.77 \mathrm{~km}^{2}$, and the number of inhabitants is 8730 (2018). The hydrographic network is represented by Brynica, belonging to the Vistula river basin, with its tributaries Jaworznik and Wielonka (Figure 1). In the geological structure, Wojkowice is located in the Bytom basin made of Triassic deposits, underlain by productive Carboniferous deposits (with hard coal seams) and covered with discontinuous sand-clay deposits of the Quaternary. The Wojkowice region is located in the north-eastern part of the Main Groundwater Basin (MGB), Bytom [37], with its range of outcrops of Muschelkalk and Röth. Muschelkalk is formed of limestone and dolomite, including ore-bearing dolomite, and Röth is made up of marly-dolomitic formations, with limestone on the upper side. The aquifer of Muschelkalk is intensively drained by the mine workings of the closed $\mathrm{Zn}$ and $\mathrm{Pb}$ ore mines, located south of the Brynica riverbed. The degree to which the groundwater is endangered by sources of pollution is very high [38]. 


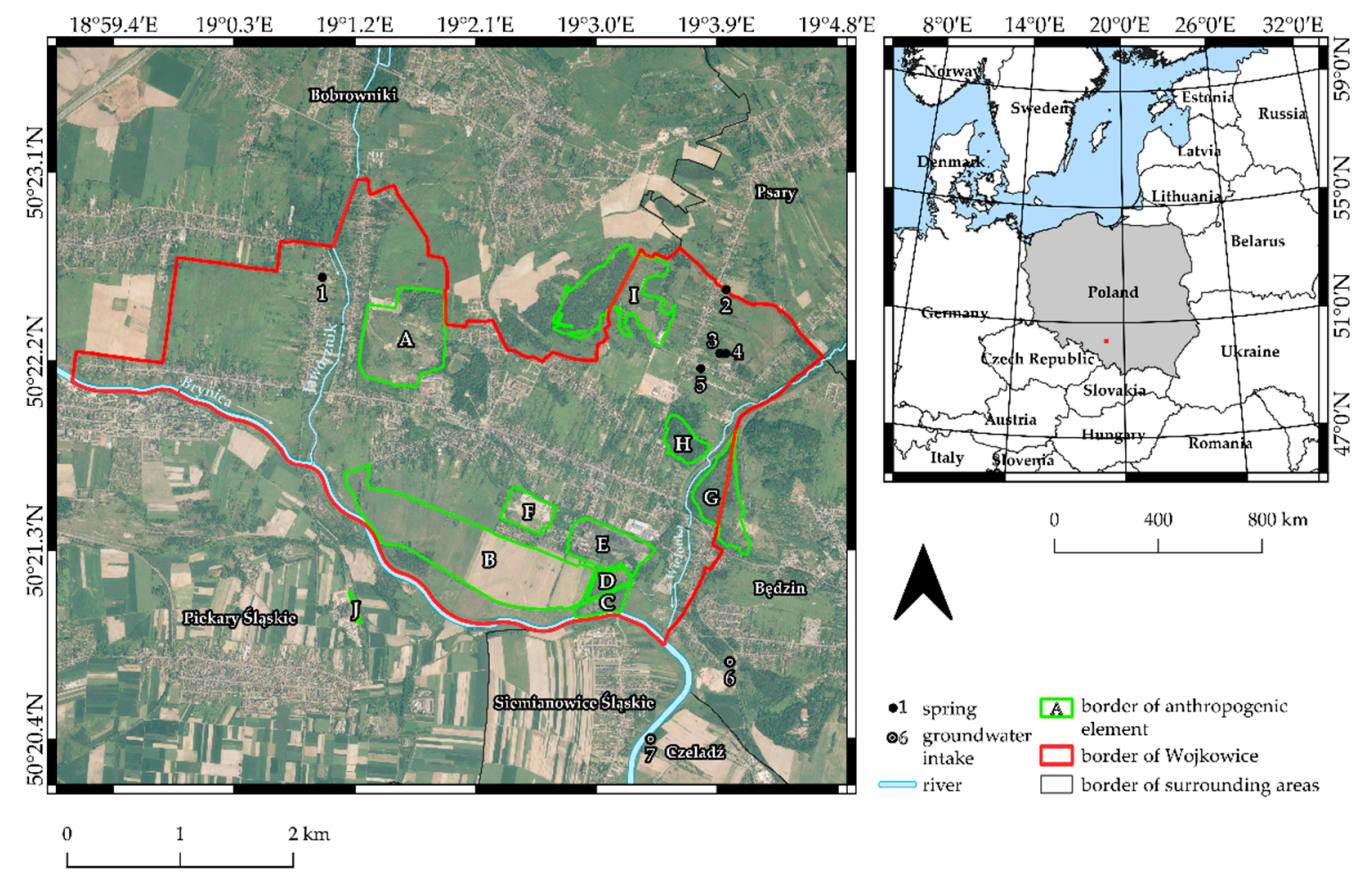

Figure 1. Location of Wojkowice in Europe. Spring: 1-Spring "Stara 107", 2-Spring "U Wnuka", 3-Spring "Brzeziny", 4-Spring "Spod morwy", 5-Spring "Długosza 36", 6-deep well "Rozkówka R-1", 7-deep well "Przełajka-3". Anthropogenic elements: A-Limestone quarry of the "Saturn" Cement Plant, B-Collective Farm "Przyjaźń", C-Waste tip no. 2 of "Jowisz" Coal Mine, D—Waste tip no. 1 "Jowisz" Coal Mine, E-Post-industrial areas of "Jowisz" Coal Mine, F-Post-industrial areas of "Saturn" Cement Plant, G-Sub-surface waste tip of "Grodziec" Coal Mine, H-“Uciekaj" Bootleg Mine, I-Limestone Quarry of “Grodziec" Cement Plant, J—“Dąbrówka” Zinc and Lead Mine $[39,40]$.

In Wojkowice, there are resources of hard coal as well as Triassic limestone and dolomite which previously contained zinc, lead and silver ores (used up in Medieval times). Dynamic development of industry in Wojkowice started at the beginning of the 20th century. At that time "Jowisz" Coal Mine was set up, which occupied a mining area of $12.00 \mathrm{~km}^{2}$. It operated from 1912 to 2000. In the period from 1932-1937 in the eastern part of the town, local people extracted shallow deposits of coal (at a depth of 2-5 m) as bootleg mining. At that time this area was called the "Uciekaj" ("Runaway") mining area. In the period from 1930-2001, side by side with "Jowisz" Coal Mine, "Saturn" Cement Plant was working, which covered an area of 12.00 ha. For the needs of the cement plant, mineral resources from the nearby "Spiny" quarry were extracted after 1929. The plant produced, among other products, high-quality Portland cement [41]. Despite the fact that in the 1990s Wojkowice lost its industrial character (liquidation of "Jowisz" Coal Mine and "Saturn" Cement Plant) [42], the town contains anthropogenic elements which have witnessed over 100 years of mining history (Figure 1 ).

\section{Materials and Methods}

The materials applied in the research included maps and remote sensing materials. Such components of landscape as land relief, land use, vegetation and underground water were studied in detail. A detailed description of materials and methods used in the research is shown below in the description of each aspect of landscape components.

\subsection{Relief and Land Use Studies}

The analysis of contemporary and archival maps and remote sensing materials made it possible to reconstruct the relief of the area studied and to show its present relief. The 
contemporary ground cover of the area studied was investigated with the application of CORINE Land Cover 2018 (CLC 2018, Copernicus program), with a resolution of $100 \mathrm{~m}$ [43].

In order to reconstruct the relief of the Wojkowice area, the following sheets of archival topographic maps of the Dabrowa Basin at a scale 1:10,000 were used: Rogoźnik [44], Strzyżowice [45], Kol. kop. Jowisz-Dąrówka Wielka [46] and Grodziec [47], published in 1929. Reconstruction of the relief was carried out using a geostatistical interpolatorordinary kriging $[19,48,49]$. However, because of a lack of information concerning the depth of the channel of the Brynica, the Wielonka and the Jaworznik, these water courses were omitted. The contemporary relief of the area studied was obtained based on a digital elevation model (DEM) with a resolution of $1 \mathrm{~m}$, which was prepared based on airborne laser scanning (2011).

In order to better analyze and exhibit changes in the relief of Wojkowice which originated as a result of human impact, a differential model (DFM) was created, which was based on reconstructed and contemporary models according to the formula below:

$$
\mathrm{DFM}=\mathrm{PR}-\mathrm{RR},
$$

where DFM is the differential model, PR is the present relief and PR is reconstructed relief. Maps and models were prepared in QGIS 3.10.12 (QGIS Geographic Information System. QGIS Association. http:/ / www.qgis.org, accessed on 16 January 2021) and Surfer 19 software (Golden Software, Golden, CO, USA).

\subsection{Vegetation Study}

In order to determine the diversity of vegetation, field studies were carried out to identify the main types of phytocoenoses covering the study area. Vegetation communities were identified based on characteristic species for syntaxonic units $[50,51]$ or more abundant species. Plant names are given according to Flowering plants and pteridophytes of Poland [52].

\subsection{Hydrogeological Researches}

In the period November 2020, hydrological and land development mapping was performed on an area of approximately $10 \mathrm{~km}^{2}$. An assessment of quantitative changes in the groundwater was presented based on the subject literature presented in chapter 4.3.1. For the assessment of water quality, archival data for the deep-water intakes "Rozkówka R-1" and "Przełajka 3" from 2007-2015 were used, as were the results of chemistry and microbiological tests of water from two deep wells and five springs from June 2016 [53] and the unpublished results of research on the water chemistry of thirteen springs from November 2015 to March 2019.

The objects of the hydrogeological research are five springs located in Wojkowice ("Stara 107" No. 1, “U Wnuka" No. 2, "Brzeziny" No. 3, "Pod Morwa" No. 4, "Długosza 36 " No. 5) and eight springs in the equivalent neighboring area which represent a shallow water circulation system in the Triassic reservoir and two deep wells, "Rozkówka R-1" (No. 6) in Będzin and "Przełajka 3" in Czeladź (No. 7), representing a deeper circulation system (Figure 1, Tables S1, S2A,B and S3).

These were the first studies of the chemistry of the springs located in Wojkowice. Together with the comparative springs located in the vicinity of Wojkowice, 48 samplings and research of groundwater chemistry were performed in the period from November 2015 to March 2019. From 1 to 6 tests were performed at individual points.

In the field, water temperature and EC were tested with the CC-401 meter and the $\mathrm{pH}$ with the CP-315 meter, both by Elmetron. Samples for chemical analyzes were collected in plastic containers. After transporting to the laboratory, the water samples were filtered on membrane filters with a pore diameter of $0.45 \mu \mathrm{m}$. The samples for cation analysis were acidified with $\mathrm{HNO}_{3} 2 \mathrm{mmol} \mathrm{L}{ }^{-1}$. The tests were performed in the Laboratory of Environmental Analyzes of the University of Silesia in Katowice, using the ion chromatography method with the use of the Metrohm 850 Professional IC with a sample feeder 858 . 
Professional Sample Processor. The limits of quantification for the individual analyzed ions ranged from 0.01 to $0.03 \mathrm{mg} \mathrm{L}^{-1}$ (Table S3).

In June 2016, employees of SGS Pszczyna performed accredited sampling from 4 springs in Wojkowice and 2 deep wells. The chemistry of the sampled waters was tested in the certified Laboratory of SGS Poland, Environmental Laboratory, Pszczyna, Poland (ilac MRA; PCA Polish Center for Accreditation; no AB 1232) (Table S1).

In order to characterize the water chemistry of the deeper circulation system, the results of the research on the chemistry of groundwater from the "Rozkówka R-1" and "Przełajka-3" deep wells from 2007-2015, were published in MONBADA, the groundwater quality monitoring base of the State Environmental Monitoring. Accredited groundwater sampling in national monitoring was performed usually twice a year (in spring and autumn) by employees of the Polish Geological Institute-National Research Institute, and the chemistry of the sampled waters was tested in the certified Laboratory of Polish Geological Institute-National Research Institute in Warsaw, which holds the certificate of the Polish Center of Accreditation no AB 283. In total, 28 water samples were examined in the above-mentioned deep wells in 2007-2015. (Table S2A,B).

\section{Results and Discussion}

\subsection{Changes in Relief and Land Use}

As a result of our studies, hypsometric maps and digital elevation models (DEMs) were obtained which show both the reconstructed relief before the beginning of anthropogenic activity and the contemporary relief of Wojkowice (Figures 2 and 3). In order to emphasize the results of mining activity, a differential model (DFM) (Figure 4a) was created and a topographic profile was marked out (Figure 2a,g) across the most transformed parts of Wojkowice. This was supplemented with a map of ground cover from CORINE Land Cover 2018 [43]. This made it possible to carry out a comprehensive analysis and evaluation of relief transformation in the area studied.

The area of present-day Wojkowice has been drastically transformed by human impact. The original relief of Wojkowice showed numerous denivelations. It contained hills, depressions, and river valleys. The elevation was in the range of 260-366 m.a.s.l. (Figure 2a,c,e). The analysis of contemporary maps and DEM showed that at present the elevation is in the range of 254-365 m.a.s.l. (Figure $2 \mathrm{~b}, \mathrm{~d}, \mathrm{f}$ ). As a result of anthropogenic activity, the ground surface has dropped by about $5 \mathrm{~m}$. Such large changes in relief occurred as a result of the activity of former extractive and processing plants which worked for many years in Wojkowice [41]. Many industrial objects connected with mining activity have been developed in Wojkowice. They have strongly influenced the contemporary landscape of the town. They are mainly located in the northern, southern and south-eastern parts of the town (Table 1, Figure 1).

Table 1. Specification of the most important anthropogenic elements in the area studied.

\begin{tabular}{ccccc}
\hline Name of Anthropogenic Element & ID $^{\mathbf{1}}$ & Area [ha] & State of Reclamation & Contemporary State of Land Use \\
\hline Limestone quarry of "Saturn" Cement Plant & A & 50 & PR & Partly buried with coal gangue \\
Collective Farm "Przyjaźn" & B & 102 & R & Levelled subsidence depressions and fissures \\
Waste tip no. 2 of "Jowisz" Coal Mine & C & 6.8 & PR & Demonded demolition \\
Waste tip no. 1 "Jowisz" Coal Mine & D & 5.9 & R & Pemd grassed \\
Post-industrial areas of "Jowisz" Coal Mine & E & 22.5 & PR & infrastructure \\
Post-industrial areas of "Saturn" Cement Plant & F & 12 & NR & Totally demolished infrastructure developed \\
Sub-surface waste tip of "Grodziec" Coal Mine & G & 25 & F & Forest reclamation \\
"Uciekaj" Bootleg Mine & H & 9.7 & NR & Tree-covered \\
Limestone Quarry of "Grodziec" Cement Plant & I & 48 & PR & Partly buried and covered by plants \\
\hline
\end{tabular}

${ }^{1}$ ID number consistent with Figure 1, PR—partially reclaimed, R-reclaimed, NR—no reclamation. 

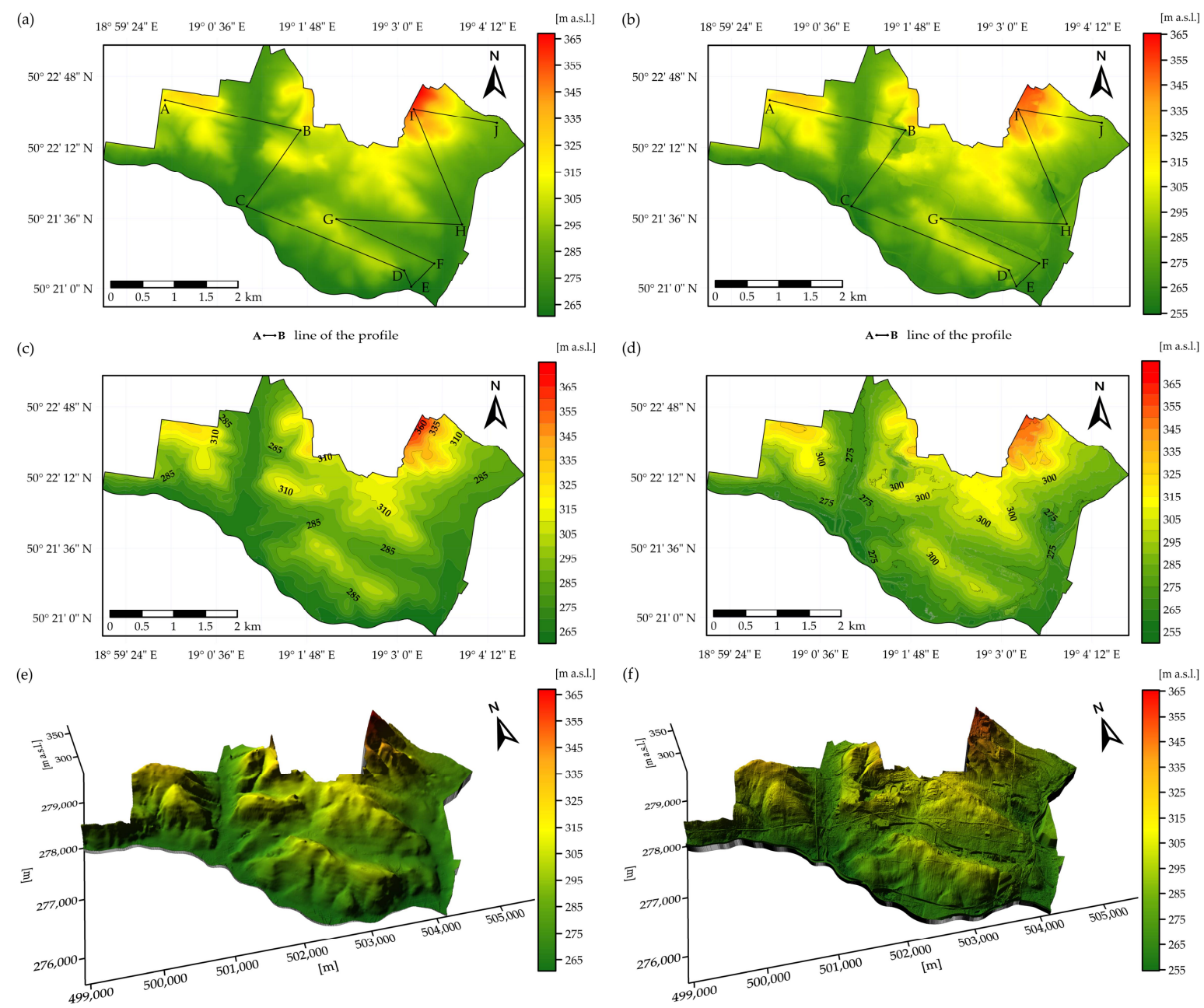

(g)

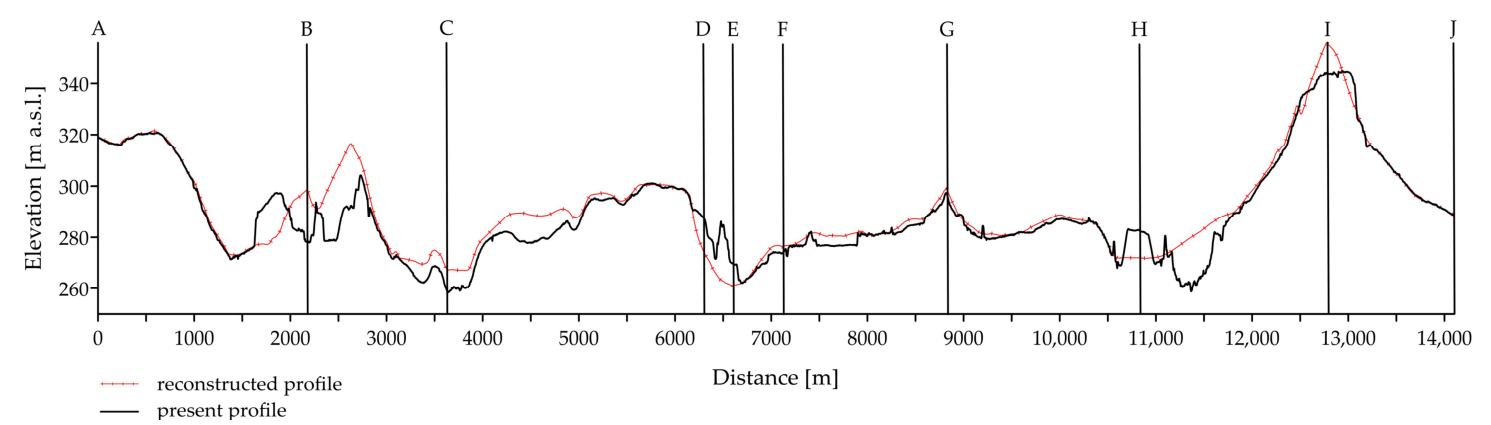

Figure 2. Changes in the relief of Wojkowice. Relief before the beginning of human impact: (a)—color relief map with topographic profile, (c)—hypsometric map, (e)—digital elevation model (DEM). Contemporary relief: (b)—color relief map with topographic profile, (d)—hypsometric map, (f)—digital elevation model (DEM); (g) topographic profile including reconstructed relief and present relief.

In order to better display the largest transformations of the landscape in Wojkowice, a 14,000 m long line of topographic profile A-I (Figure 2a,b,g) was marked across these objects (Figure 2g). In profile A-B, at a distance of 1900 to $2600 \mathrm{~m}$, there is a depression which originated due to extraction activity of the "Saturn" Cement Plant. As a result of mining, this area has dropped by almost $36 \mathrm{~m}$ (from 315 to $279 \mathrm{~m}$ a.s.l.) (Figure 3). 


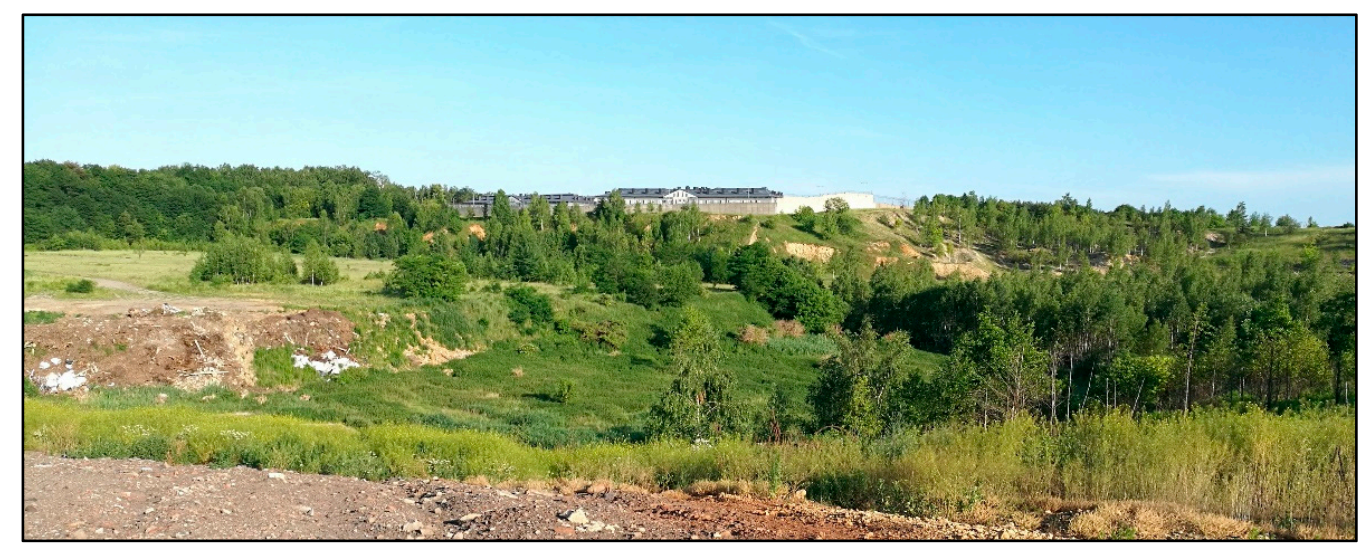

Figure 3. View towards the south-east showing part of the "Saturn" Cement Plant (in the background is the penitentiary in Wojkowice). Photo by A. Zarychta.

In section B-C-D, at a distance of 3000 to $5100 \mathrm{~m}$, mining subsidence is observed. This area now belongs to the Collective Farm "Przyjaźń". The land has dropped by $10 \mathrm{~m}$. The subsidence was caused by coal extraction in the "Jowisz" Coal Mine. Profile D-E (6200-6600 m) shows an overburden of extracted material-the height of the waste tip reaches $24 \mathrm{~m}$. The ground rose from 259 to 183 m.a.s.l., mainly in the south-eastern part where two waste tips (No. 1 and No. 2) of the "Jowisz" Coal Mine were located. The next section of profile F-G runs across the industrial area of the former "Jowisz" Coal Mine and "Saturn" Cement Plant (7500-8600 m). Ground levelling necessary for the construction of both plants caused the surface to drop by $7 \mathrm{~m}$ (from 278 to $271 \mathrm{~m}$.a.s.l.). Section G-H runs along the part of the town where no industrial activity was carried out. Only its terminating part, at a distance of 10,600 to $11,000 \mathrm{~m}$, runs across the reclaimed sub-surface waste tip of "Grodziec" Coal Mine. Originally, this area was located at 265 m.a.s.l. As a result of extracting activity, the coal gangue from several coal mines, including "Jowisz" Coal Mine, was dumped there. The tip is $14 \mathrm{~m}$ high and reaches an altitude of $279 \mathrm{~m}$.a.s.l. Profile H-I runs towards the north-west, where the "Uciekaj" Mine (11,200-11,700 m) used to operate with bootleg mining. Uncontrolled coal extraction by local people resulted in the development of a $25 \mathrm{~m}$ deep excavation, and the ground surface dropped from 282 to 260 m.a.s.l. Due to processes of plant succession, the excavation regenerated and is now overgrown by forest. The terminating part of section $\mathrm{H}-\mathrm{I}$ and beginning of section $\mathrm{I}-\mathrm{J}$ $(12,500-13,100 \mathrm{~m})$ includes part of the reclaimed Limestone Quarry of "Grodziec" Cement Plant. Limestone excavation caused the ground to drop by about $15 \mathrm{~m}$ (from 360 to 345 m.a.s.l.).

The scale of the transformation in Wojkowice is well visible by Differential Model (DFM) (Figure 4a). Its analysis made it possible to determine changes in elevation at the level of about $55 \mathrm{~m}$. The height values in the most extreme places range from -29 to $+26 \mathrm{~m}$. This shows the scale of the transformation of the Wojkowice area.

The two largest enterprises, "Jowisz" Coal Mine and "Saturn" Cement Plant, which were the most responsible for relief transformation, do not work in the town anymore. There are only some remnants in the form of partly developed post-industrial areas (Figure $2 b, d, f$ and Figure $4 b$ ). Figure $4 b$ shows the development of discontinuous urban fabric along the main roads and close to former excavating and processing plants. The largest transformations which occurred in the last century mainly caused lowering of the land in the southern part of the town (Figure 4). According to CLC 2018 [43], these areas now represent pastures and non-irrigated arable land. Moreover, industrial units are still visible, such as the excavation in the northern part of the town, which was partly reclaimed and now represents green urban areas (Figure $4 b$ ). Former post-mining objects located in the northern and eastern parts of the town, which were working in the 1960s-1990s, were reclaimed and replaced by broad-leaved forest and transitional woodland-shrubs. 
(a)

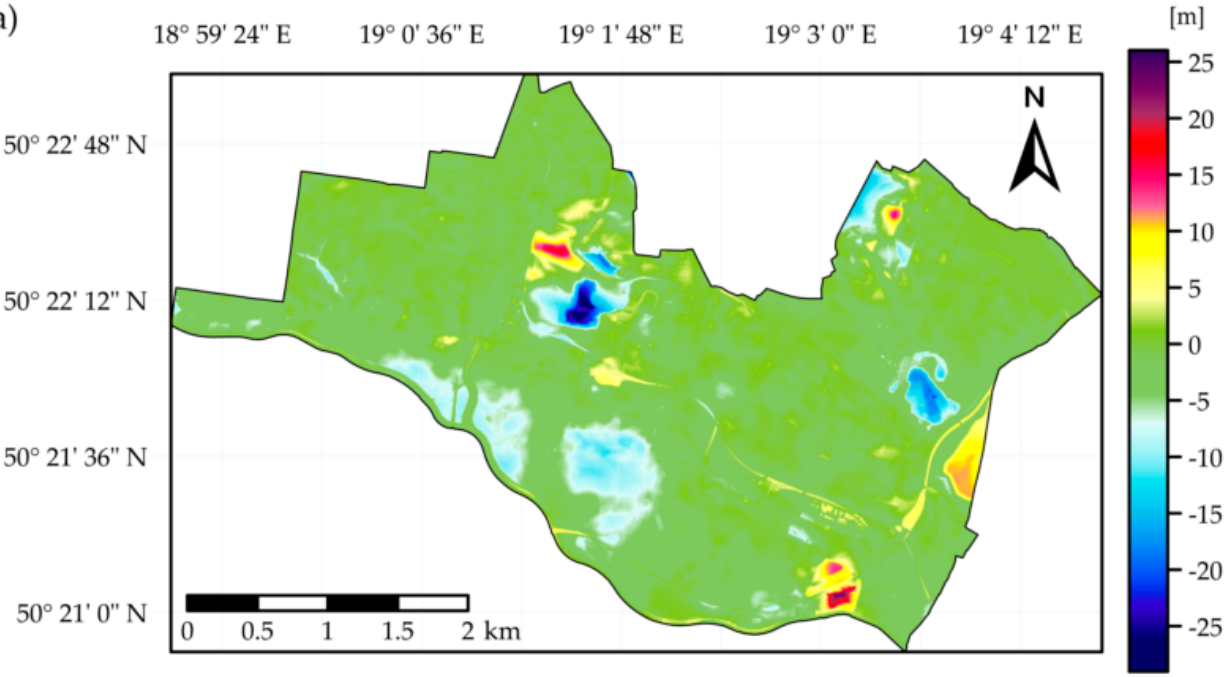

(b)
$18^{\circ} 59^{\prime} 24$ " E
$19^{\circ} 0$ ' 36" E
$19^{\circ} 1^{\prime} 48^{\prime \prime} \mathrm{E}$
$19^{\circ} 3^{\prime} 0^{\prime \prime} \mathrm{E}$
$19^{\circ} 4^{\prime} 12^{\prime \prime} \mathrm{E}$

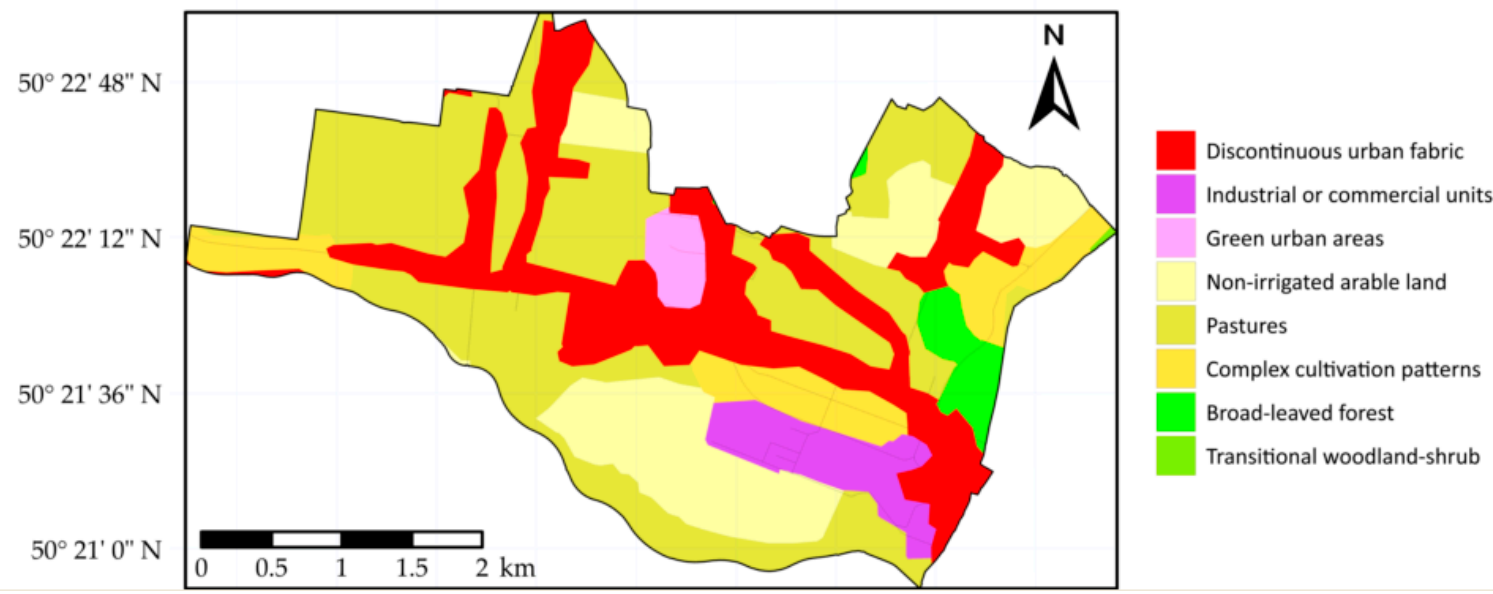

Figure 4. (a) Differential model of Wojkowice relief; (b) Contemporary model of ground cover of the Wojkowice area from CORINE Land Cover 2018 [43].

Similar transformations occurred, for example in Wałbrzych, a town located in south-western Poland, where (similarly to Wojkowice) the mining industry developed for 100 years until the end of the 1990s. The results of the research confirm that a comparison of the present relief with the reconstructed relief or historical maps makes it possible to determine time-spatial relations between the original relief and the relief which was transformed due to human impact $[18,19]$. The obtained results represent a valuable source of information concerning landscape transformation which has occurred in areas strongly transformed by human impact. They may also be very significant in future geomorphological analysis and studies connected with the development of anthropogenic areas $[17,19]$.

\subsection{Vegetation Diversity}

Before the drastic degradation of the natural environment in the study area, in accordance with geological and soil conditions, potential natural vegetation developed, such as deciduous forests of the Tilio-Carpinetum, Dentario-ennephyllidis and Fraxino-Alnetum varieties. Currently, nothing is left of these potential communities except for small patches of Fraxinus-Alnetum in the valleys of the Wielonka and Jaworznik rivers. Contemporary vegetation in Wojkowice has an anthropogenic character and does not refer to potential natural vegetation [51]. 
Currently, non-forest communities dominate within the borders of Wojkowice, and forest ecosystems occur in a small area in scattered forms. The largest dense forest complex is the Town Park located in the central part of Wojkowice (Figure 4b), which is artificial. Most of the species here were artificially introduced; they are of a similar age and their distribution is regular (even). There is practically no layer of shrubs in the forest, only tree undergrowth. The tree stand is made of native (Acer platanoides, A. pseudoplatanus, Quercus robur, Tilia cordata, Fagus sylvatica, Carpinus betulus, Betula pendula, Fraxinus excelsior, Populus tremula, Larix europeae, Picea abies, Pinus sylvestris) and alien trees species (Acer negundo, A. saccharinum, Quercus rubra, Robinia pseudacacia). The forest is mixed, with local dominance of individual species, such as Pinus sylvestris or Betula pendula in the north-west and Picea abies in the east. The undergrowth is poor in species due to the expenditure of plant litter undergoing weak decomposition processes. There are also species such as Convallaria majalis, Epipactis helleborine, Hepatica nobilis, Anemone nemorosa and nitrophilic species as Aegopodium podagraria, Cheledonium majus often occurs in the form of a monospecies (single-species) patches.

It can be predicted that, in the northern part of the Town Park, near the mining dump, ecological processes are taking place leading to the re-naturalization of the oak-hornbeam forest. This is very important for the proper functioning of the forest within anthropogenic systems. The forest complex of the Town Park is a critical habitat within the town, and its key role is to preserve the local population of plants and animals. The remaining initial forests were often created due to artificial plantings and spontaneous succession, especially in open areas. In terms of species composition in these forests, apart from the native species Betula pendula, Acer platanoides, A. pseudoplatanus, Quercus robur, Populus tremula, Pinus sylvestris, there are many alien trees species: Acer negundo, Quercus rubra, Robinia pseudoacacia, Pinus nigra and shrubs such as Padus serotina, Symphoricarpos albus.

Along the Brynica River, Wielonka, and in the upper section of the Jaworznik streams on the border of Wojkowice, riparian forests characteristic for this type of habitat have formed (Figure 1) with the participation of Alnus glutinosa, Salix fragilis, Salix pentandra and Sambucus nigra. These phytocenoses are closest to a natural species composition and typical of the riparian community of the Alno-Ulmion and the alder community of the Alnion-glutinosae union (including Ribeso nigri-Alnetum) in the unregulated sections of the Wielonka and Jaworznik valleys, mainly made up of Alnus glutinosa.

Concerning shrub communities, in the north-east of the town, a small fragment of agricultural landscape has been preserved where a natural fringe community and thickets from the class of Rhamno-Pruneteae and the order of Prunetalia spinosae grow. These are dominated by xeromorphic shrubs such as Prunus spinosa, Rhamnus catarcticus, Crataegus monogyna, Rosa canina and often Corylus avellana. This community is scattered throughout the area, mainly in unused agricultural areas on the quarry's outskirts in "Żychcice-Saturn" and post-limestone pits (Figure 1) or other hills on the town border. These communities also create habitats for many organisms associated with open areas and inhibit soil erosion processes.

The non-forest (herbaceous) communities in the town's ecosystem mainly consist of arable fields and wastelands at various stages of succession (Figure 5). Small areas are represented by xerothermic grasslands occurring in new ecological niches and the largest complexes of these grasslands develop within the inactive post-limestone workings of the "Saturn" Cement Plant (Figure 1).

The exploitation of mineral resources resulted in the development of new habitats for various ecological groups of plants. Such habitats include the remains of a limestone quarry in the northern part of the town (Figure 1), where thermophilic xerothermic grasslands of the Festuco-Brometea class developed, among others, with Brachypodium pinnatum, which are typical for sunny areas and calcareous soils. Another example of anthropopressure habitats are former warpies (holes and heaps from removed waste rock after mining activities) with populations of protected species such as Carlina acaulis and Epipactis atrorubens.

Ruderal habitats and related anthropogenic communities (Figures 3 and 5), mainly from the Dauco-Melilotenion union and the Artemisietea vulgaris class, which include ni- 
trophilic communities of vigorous perennials and creepers in ruderal habitats on the banks of watercourses and ponds. The ruderal communities occupied more areas than other types of vegetation in Wojkowice town landscape.

Unused farmland is subject to spontaneous succession often initiated by Solidago canadensis (Figure 5). This is an invasive species which is native to North America and characteristic of the Rudbeckio-Solidaginetium association. Calamagrostietum epigeji communities naturally colonize agricultural wastelands and reclaimed areas associated with municipal waste (Żychcice-Saturn and post-limestone quarry-Figure 1) in the form of large patches. It creates single species aggregations and makes it difficult for other species to encroach.

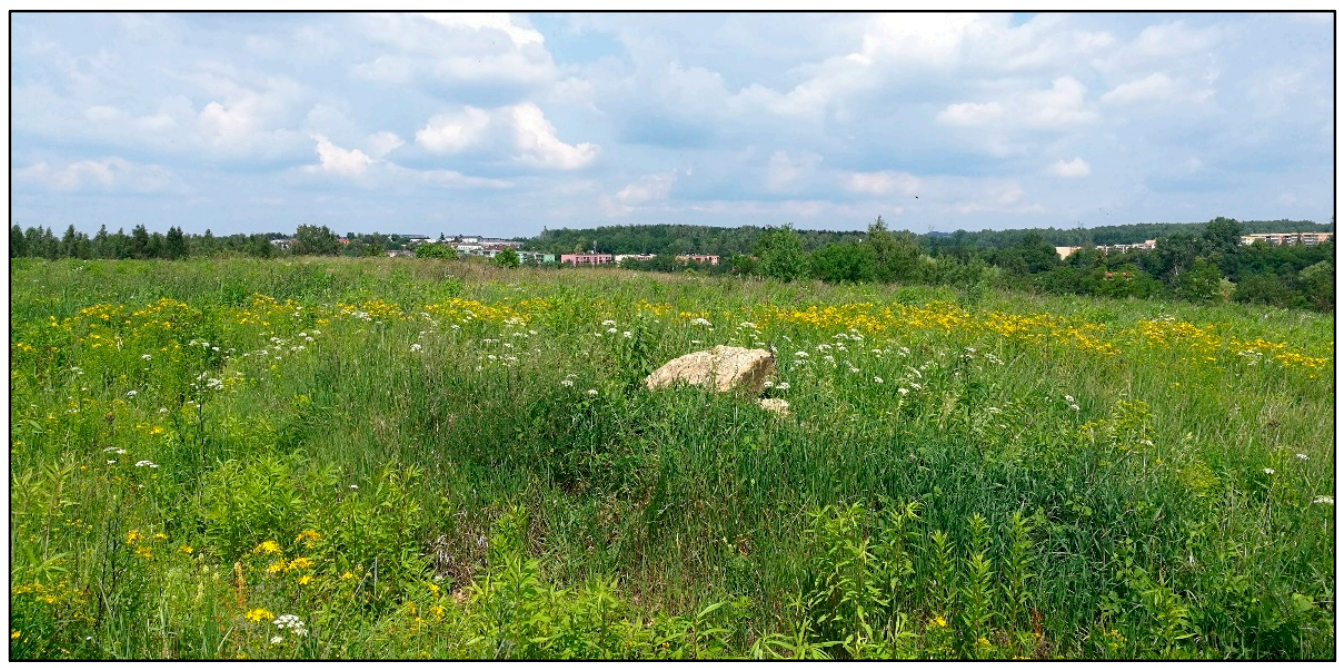

Figure 5. The patches of Solidago canadensis in agriculture wasteland. Photo by R. Zarychta.

The river system underwent anthropogenic transformations through the regulation of the Brynica River and other streams; the area is therefore poor in surface reservoirs. Therefore, aquatic and rush vegetation does not occur in large patches, but only where there are favorable water conditions. The patches are usually small in area and are irregularly distributed in the river valleys, streams and in stagnant waters (Figure 1). These communities are usually characterized by single-species aggregations with participation of Phragmitetum australis, Typhetum latifoliae, Lythro-Filipenduletum ulmariae, Equisetetum fluviatilis Caricetum rostratae, Caricetum, nigrae, and Caricetum gracilis. These communities underwent changes in the drained parts of the area and their places were taken by species associated with fresh habitats. This kind of transformation of vegetation was also observed in the neighboring areas [54].

As in other post-mining landscapes, in non-reclaimed areas vegetation succession is mainly initiated by Calamagrostis epigejos $[55,56]$. This grass is characterized by high ecological flexibility and a wide spectrum of nutritional requirements. Its extensive root system supports the absorption of nutrients not only from the ground, but also from atmospheric downfalls. The rapid process of land colonization of this species leads to turf formation on the soil surface which, in turn, inhibits erosive processes [33,36].

\subsection{Groundwater}

\subsubsection{Quantity Changes in Groundwater}

The extreme southern part of Wojkowice belonged to the "Dabrówka" mining field. The ore mine "Dabrówka" was the east part of the "Orzeł Biały" Mining and Metallurgical Plant (MMP). The object of work carried out in the mine from 1973-1988 was the $\mathrm{Zn}$ and $\mathrm{Pb}$ ore appearing as irregular nests in Triassic dolomites. The primary mining level of the mine was $64 \mathrm{~m}$ deep. The water regime of the Muschelkalk aquifer was disturbed by the drainage activity of mining and the exploitation of water with deep wells. The initial water table appeared at a height of about 265 m.a.s.l., i.e., at the absolute height of the water table 
of the Brynica River. In 1980, the water table of the Muschelkalk aquifer was established in the whole MMP "Orzeł Biały" at a height of 202-210 m.a.s.l., i.e., it had dropped by 55-63 m. The inflow of water to the "Dabrówka" minefield was from 1.8 to $5.5 \mathrm{~m}^{3} / \mathrm{min}$ in the years 1968-1975 and from the neighboring "Orzeł Biały" and "Dabrówka" mining fields it reached as much as $17.4 \mathrm{~m}^{3} / \mathrm{min}[57,58]$. The width of the mining drainage zone was $6.5 \mathrm{~km}$. As a result of mining activities of $\mathrm{Zn}$ and $\mathrm{Pb}$, the Muschelkalk aquifer was usually drained, and only the Röth aquifer is still usable.

After the cessation of mining in the Bytom basin and the liquidation of five ore mines that were connected by underground workings, in the period 1978-1989, the entire inflow of water to the mining areas was taken over by the Central Pumping Station at the "Bolko" shaft (CPS) located approximately $8 \mathrm{~km}$ west of Wojkowice. The need for further drainage of the workings of the liquidated ore mines resulted from the water hazard for mines exploiting hard coal deposits in the Bytom region. The analysis showed that, after the pumping station was stopped, the mine water naturally reached the "Bolko" shaft from the "Dabrówka" mining field after 120-150 days [58]. In 2016, water inflows from the "Dabrówka" mining field amounted to $5.0-5.5 \mathrm{~m}^{3} / \mathrm{min}$, with the average total inflow to the CPS (1989-2016) in the amount of $26.2 \mathrm{~m}^{3} / \mathrm{min}$ [59]. In the area of Wojkowice, in the years 1912-2000, the "Jowisz" mine also exploited a hard coal deposit (mainly seams with numbers 500, 600, at a depth interval of 70-550 m). The inflow of water from the Carboniferous rock mass did not exceed $5 \mathrm{~m}^{3} / \mathrm{min}$. The exploitation of hard coal was accompanied by land subsidence and linear deformations on the surface (fractures, ditches) which were reclaimed during the closure of the mining plant (Figure 2). The authors do not have hydrogeological maps available during the MMP "Orzeł Biały" activity. The hydrodynamic conditions of mainly the Röth aquifer at the end of the 20th century in the area of Wojkowice are presented in Figure 6.

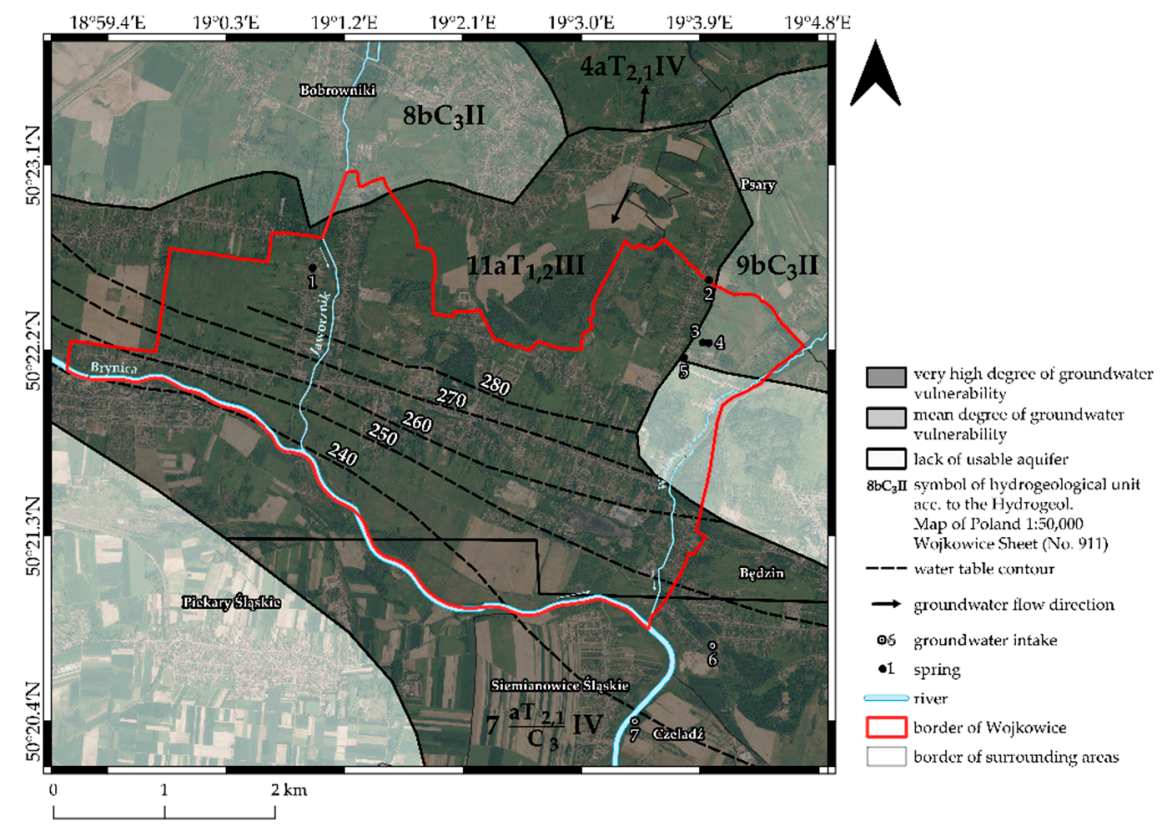

Figure 6. Location of the research points according to the Hydrogeological Map of Poland 1:50,000, Wojkowice Sheet (No. 911) [38].

\subsubsection{Groundwater Chemistry and Quality}

Chemical composition of groundwater in the Triassic carbonate series is conditioned by geological and anthropogenic factors. In the environment of Triassic carbonate rocks in the zone of the active groundwater flow, waters of the $\mathrm{HCO}_{3}-\mathrm{SO}_{4}-\mathrm{Ca}-\mathrm{Mg}$ type dominate, forming under the conditions of carbonate equilibrium. 
The waters studied, similar to the Triassic (mainly Röth) carbonate series of the MGB "Bytom", are transformed, which is favored by a very high degree of groundwater endangering (Figure 6). They are characterized by increased mineralization, multi-ionic types of water, high concentrations of $\mathrm{SO}_{4}, \mathrm{NO}_{3}, \mathrm{Cl}, \mathrm{Na}, \mathrm{Mg}$ ions, and total hardness (especially in deep water intakes) $[37,38]$.

The waters of the "Przełajka-3" intake, examined in 2007-2016, were characterized by increased mineralization (electric conductivity (EC) 869-1512 $\mu \mathrm{S} / \mathrm{cm}$ ), multi-ionic types of water: $\mathrm{HCO}_{3}-\mathrm{Cl}-\mathrm{SO}_{4}-\mathrm{Ca}-\mathrm{Mg}-\mathrm{Na}, \mathrm{HCO}_{3}-\mathrm{SO}_{4}-\mathrm{Cl}-\mathrm{Ca}-\mathrm{Mg}-\mathrm{Na}, \mathrm{HCO}_{3}-\mathrm{SO}_{4}-\mathrm{Cl}-\mathrm{Ca}-\mathrm{Mg}$ and mainly quality class III. In class III there were concentrations of $\mathrm{NO}_{3}$, as well as $\mathrm{Ca}, \mathrm{Mg}$, periodically $\mathrm{Zn}, \mathrm{PO}_{4}, \mathrm{Cl}$, and in class $\mathrm{IV}$ concentrations of $\mathrm{SO}_{4}$, with quality class $\mathrm{IV}$ denoting a poor chemical state of the water. Groundwater quality classes and chemical state of the water defined according to Regulation of the Minister of Maritime and Inland Navigation of 11 October 2019 on the criteria and method of assessing the status of groundwater bodies (Journal of Laws 2019, item 2148) [60].

The concentrations of the tested macrocomponents were in the ranges, at an average value, as follows: Ca 112-155 (129); Mg 35.3-60.7 (52.5); Na 25.9-94.5 (62.8); K 2.7-5.6 (4.3); $\mathrm{HCO}_{3} 285-377$ (339); $\mathrm{SO}_{4}$ 177-241 (217); Cl 49.9-159 (99.2); $\mathrm{NO}_{3} 26.4-41.9$ (37.4); $\mathrm{PO}_{4}<0.1\left(\mathrm{mg} \mathrm{L}^{-1}\right)$ (Table 2, Tables S1 and S2A,B).

The microelements concentrations in groundwater are low and show the following range and mean value: As < 0.002; B 0.08-0.24 (0.165); $\mathrm{Cr}<0.003$; Zn 0.63-0.97 (0.79); $\mathrm{Al}<0.0005-0.0035$ (0.0011); Cd 0.0005-0.0012 (0.0009); $\mathrm{Mn}<0.001-0.003(<0.001)$; $\mathrm{Cu}$ 0.0012-0.0035 (0.0018); $\mathrm{Ni}<0.0005-0.0021$ (0.0006); $\mathrm{Pb}<0.00005-0.00012$ (0.00006); $\mathrm{Hg}<0.0003 ; \mathrm{Fe}<0.01-0.02$ (0.01) $\left(\mathrm{mg} \mathrm{L}^{-1}\right)$ (Table S2A,B).

The water of the "Rozkówka R-1" intakes, examined in 2007-2016, was also characterized by increased mineralization (EC from 976 to $1332 \mu \mathrm{S} / \mathrm{cm}$ ), a multi-ionic type of water $\mathrm{HCO}_{3}-\mathrm{SO}_{4}$-Ca-Mg and mainly quality class IV (high concentrations of $\mathrm{NO}_{3}$ and $\mathrm{SO}_{4}$ in the water). In quality class III, mostly concentrations of $\mathrm{Ca}, \mathrm{Mg}, \mathrm{HCO}_{3}, \mathrm{PO}_{4}$, and $\mathrm{Zn}$ were found. $\mathrm{NO}_{3}$ concentrations in the water increased dynamically in the 21st century exceeding the limit values for drinking water $\left(50 \mathrm{mg} \mathrm{NO}_{3} \mathrm{~L}^{-1}\right)$. In the waters of both wells, the limit values for drinking water were occasionally exceeded in relation to $\mathrm{SO}_{4}, \mathrm{Mg}$, and total hardness, which is conditioned by the presence of the carbonate rock environment (Table 2). Increased $\mathrm{Zn}$ concentrations may also be of a geogenic nature as in the water environment of sterile carbonate rocks Zn concentrations decrease [61].

The concentrations of the tested macrocomponents were in the ranges, at an average value, as follows: Ca 132-153 (144); Mg 65.8-75.4 (68.8); Na 32.1-50.6 (37.5); K 7.5-10.3 (8.8); HCO3 373-443 (407); $\mathrm{SO}_{4} 224-264$ (253); Cl 50.7-73.4 (60.2); $\mathrm{NO}_{3}$ 49.8-62.8 (56.6); $\mathrm{PO}_{4}<0.1\left(\mathrm{mg} \mathrm{L}^{-1}\right)$ (Table 2, Tables S1 and S2A,B).

The microelements concentrations in groundwater are low and show the following range and mean value: As < 0.002; B 0.16-0.27 (0.18); $\mathrm{Cr}<0.003-0.022(<0.003)$; Zn 0.45-0.55 (0.48); $\mathrm{Al}<0.0005-0.0042$ (0.0013); Cd 0.0005-0.0011 (0.0009); $\mathrm{Mn}<0.001-0.001(<0.001) ; \mathrm{Cu}$ 0.0015-0.0038 (0.0024); Ni < 0.0005-0.0019 (0.0005); Pb 0.00041-0.0026 (0.0009); Hg < 0.0003 ; $\mathrm{Fe}<0.01-0.14(0.04)\left(\mathrm{mg} \mathrm{L}^{-1}\right)$ (Table S2A,B).

The chemistry and quality of groundwater exploited by groundwater intakes are detailed in Piper's diagram (Figure 7) and in the Table S2A,B. 


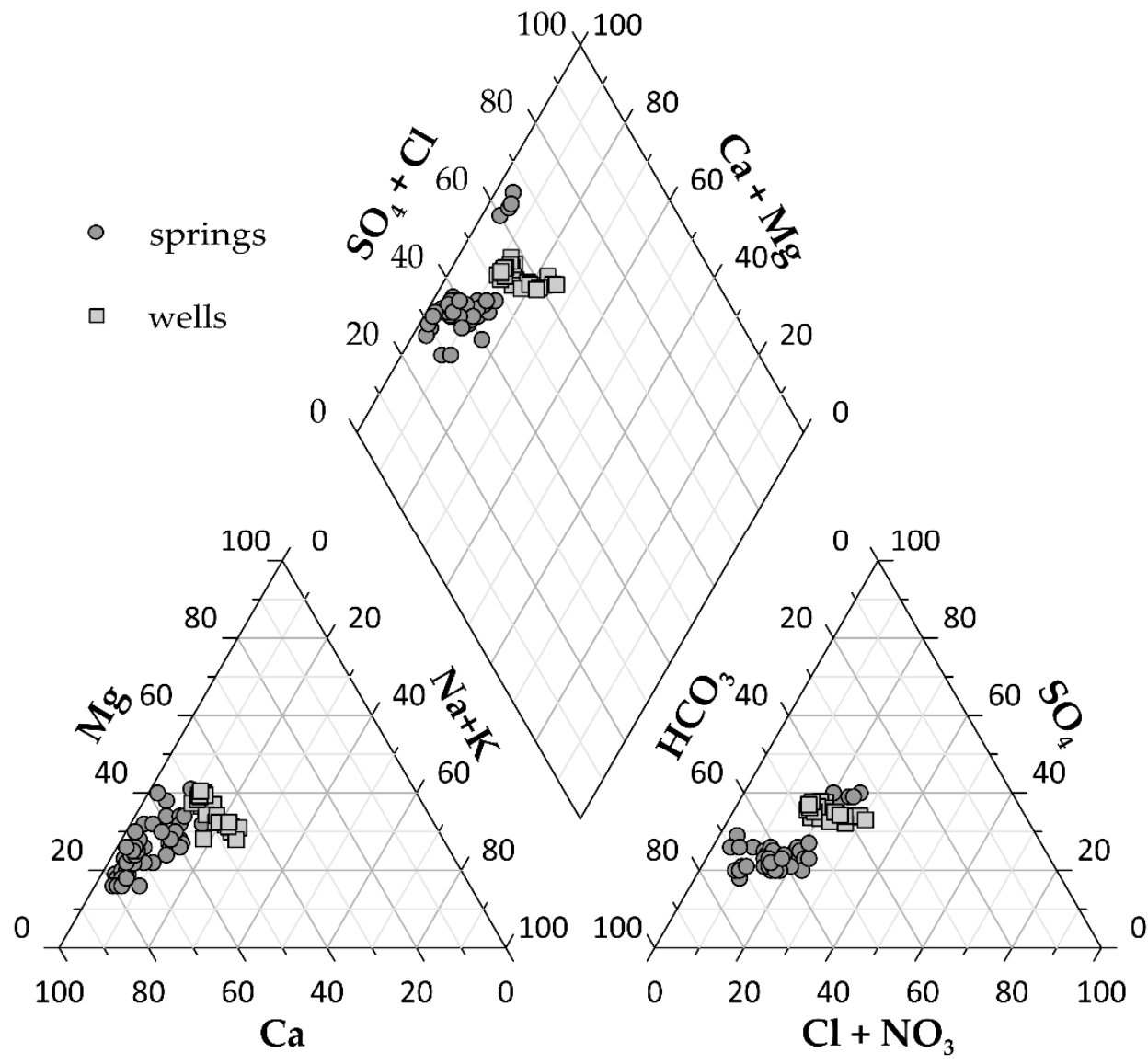

Figure 7. Piper's diagram showing the chemical composition of waters in Triassic carbonate series in the Wojkowice area and in the equivalent neighboring area.

In the published chemical analysis of mine water from the "Dabrówka" mine, to which the authors had access, from 1979, the concentrations of the components were: Dry residue 1378; $\mathrm{Ca} 228 ; \mathrm{Mg} 72.2 ; \mathrm{Na} 9.9 ; \mathrm{Zn} 4.82 ; \mathrm{Fe} 0.70 ; \mathrm{HCO}_{3} 598 ; \mathrm{SO}_{4} 304 ; \mathrm{Cl} 64\left(\mathrm{mg} \mathrm{L}^{-1}\right)$; below the limit of detection- $\mathrm{Mn}, \mathrm{Pb}, \mathrm{Cd}, \mathrm{Cu}$ [57]. The concentrations of $\mathrm{Ca}, \mathrm{HCO}_{3}, \mathrm{SO}_{4}, \mathrm{Zn}$ in mine waters were therefore higher than in the exploited waters of the groundwater in-takes "Przełajka-3" and "Rozkówka R-1", located east of the former mine "Dabrówka". It should also be remembered that the $\mathrm{Zn}$ and $\mathrm{Pb}$ ore mine "Dabrówka" ended its operations in the southern part of Wojkowice over 30 years ago. In turn, the waters drained from the springs represent only the shallow circulation system.

Springs occur in the valley drainage zone or they occur in the drainage zone on the border of the Triassic reservoir built of carbonate rocks and the Carbonate reservoir built of siliceous rocks under the conditions of anthropogenic pressure, hence the chemistry of the waters drained from these springs is geogenically and anthropogenically conditioned.

The waters of the springs examined from 2015-2019 were usually characterized by lower mineralization (EC 493-1117 $\mu \mathrm{S} / \mathrm{cm}$ ), except for the waters of the "Dlugosza 36" spring (up to $1580 \mu \mathrm{S} / \mathrm{cm}$ ); they are slightly acidic to slightly alkaline (pH 6.50-8.30), usually hard and very hard (total hardness $335-650 \mathrm{mg} \mathrm{CaCO}_{3} \mathrm{~L}^{-1}$ ), and all of the $\mathrm{HCO}_{3}$ $\mathrm{SO}_{4}-\mathrm{Ca}-\mathrm{Mg}$ type. The concentrations of the tested components were in the ranges $(\mathrm{mg} / \mathrm{L})$ : $\mathrm{Ca}$ 66-182; $\mathrm{Mg}$ 9.6-52.8; $\mathrm{Na} 2.2-47.2 ; \mathrm{K} 0.6-10.5 ; \mathrm{HCO}_{3} 113-529 ; \mathrm{SO}_{4} 61.3-201 ; \mathrm{Cl} 5.3-88$; $\mathrm{NO}_{3} 4.6-73.1 ; \mathrm{PO}_{4}$ 0.02-0.2; $\mathrm{SiO}_{2}$ 3.6-9.8 (Table 2, Table S3). 
Table 2. Chemistry and dominant water quality of the Triassic aquifer in Wojkowice and the surrounding area (11.2015-03.2019); quality class, range of variation, average value.

\begin{tabular}{|c|c|c|c|c|c|c|c|c|c|c|c|c|c|}
\hline \multirow{2}{*}{$\begin{array}{c}\text { Number of Spring/ } \\
\text { Well Number } \\
\text { of Samples }\end{array}$} & \multirow{2}{*}{ Parameter/Location/Water Quality Class } & Temp. of Water & $\mathrm{pH}$ & $\mathrm{Ca}$ & $\mathrm{Mg}$ & $\mathrm{Na}$ & K & $\mathrm{HCO}_{3}$ & $\mathrm{SO}_{4}$ & $\mathrm{Cl}$ & $\mathrm{NO}_{3}$ & $\mathrm{PO}_{4}$ & $\mathrm{SiO}_{2}$ \\
\hline & & ${ }^{\circ} \mathrm{C}$ & - & $\mathrm{mg} \mathrm{L}^{-1}$ & $\mathrm{mg} \mathrm{L}^{-1}$ & $\mathrm{mg} \mathrm{L}^{-1}$ & $\mathrm{mg} \mathrm{L}^{-1}$ & $\mathrm{mg} \mathrm{L}^{-1}$ & $\mathrm{mg} \mathrm{L}^{-1}$ & $\mathrm{mg} \mathrm{L}^{-1}$ & $\mathrm{mg} \mathrm{L}^{-1}$ & $\mathrm{mg} \mathrm{L}^{-1}$ & $\mathrm{mg} \mathrm{L}^{-1}$ \\
\hline 1 & "Stara 107" spring & $6.4-13$ & $8.11-8.3$ & $88-110$ & $21.4-29.7$ & $4.2-5$ & $0.5-0.7$ & $313-330$ & $61.3-80.1$ & $7.4-9.8$ & $22.3-31$ & $0.07-0.2$ & $4.4-5.3$ \\
\hline $\mathrm{n}=4$ & class III & 9.2 & 8.18 & 106 & 25.8 & 4.62 & 0.6 & 322 & 70.5 & 8.42 & 25.5 & 0.12 & 4.85 \\
\hline 2 & “U Wnuka” spring & $5.1-13.5$ & 7.4-7.97 & $89-118$ & $17.2-36$ & $5.7-9.55$ & $1-1.8$ & $270-290$ & 78.3-91.1 & $13-25$ & $15-22.2$ & $0.04-0.2$ & $4.02-4.76$ \\
\hline $\mathrm{n}=4$ & class II & 8.6 & 7.76 & 99.5 & 27 & 7.9 & 1.36 & 280 & 84.6 & 18.6 & 17.55 & 0.09 & 4.39 \\
\hline 3 & "Brzeziny" spring & $6.5-10.4$ & $6.5-7.37$ & $114-146$ & $26.8-42$ & $14.5-39.8$ & $1.7-10.5$ & $359-442$ & $92.9-122.6$ & $26.7-56$ & $26.4-43.9$ & $0.02-0.2$ & $6.8-7.3$ \\
\hline $\mathrm{n}=5$ & class III & 9.0 & 7.11 & 127 & 37.3 & 24.3 & 4.11 & 392 & 109.9 & 40.1 & 33.7 & 0.084 & 7.05 \\
\hline 4 & “Pod Morwa" spring & $5.6-10.5$ & $7.83-8.14$ & $116-124$ & $31.4-45.6$ & $23.9-28.5$ & $2.2-3.12$ & $360-409$ & $115.8-141.5$ & $40-51$ & $38.1-53.2$ & $0.06-0.09$ & $6.4-7.05$ \\
\hline $\mathrm{n}=4$ & class III & 8.2 & 7.98 & 121 & 39.0 & 26 & 2.61 & 384 & 129.9 & 45.8 & 45.5 & 0.07 & 6.72 \\
\hline 5 & "Długosza 36" spring & $9-10.5$ & $6.74-6.95$ & $158-182$ & $42.0-52.8$ & $35.6-47.2$ & $4-5.8$ & $439-529$ & $147.2-201$ & $73-86$ & $42.3-73.1$ & $0.04-0.2$ & $6.9-9.1$ \\
\hline $\mathrm{n}=6$ & class IV & 9.75 & 6.875 & 174 & 47.7 & 41.4 & 4.73 & 493 & 165.1 & 80.9 & 54.5 & 0.075 & 7.9 \\
\hline $\mathrm{n}=15$ & $\begin{array}{l}\text { "Przelajka-3" }{ }^{1} \\
\text { class III }\end{array}$ & 10.8 & 7.16 & 144 & 68.8 & 37.5 & 8.8 & 107 & 253 & 60.2 & 56.8 & & n.d. \\
\hline $\begin{array}{c}7 \\
\mathrm{n}=15\end{array}$ & $\begin{array}{c}\text { well } \\
\text { "Przełajka-3" } 1 \\
\text { class III }\end{array}$ & $\begin{array}{c}10.0-11.5 \\
10.5\end{array}$ & $\begin{array}{c}7.10-7.31 \\
7.20\end{array}$ & $\begin{array}{c}112-155 \\
129\end{array}$ & $\begin{array}{c}35.3-60.7 \\
52.8\end{array}$ & $\begin{array}{c}25.9-94.5 \\
62.8\end{array}$ & $\begin{array}{c}2.7-5.6 \\
4.3\end{array}$ & $\begin{array}{c}112-155 \\
139\end{array}$ & $\begin{array}{c}177-241 \\
217\end{array}$ & $\begin{array}{c}49.9-159 \\
95.2\end{array}$ & $\begin{array}{c}26.4-41.9 \\
37.4\end{array}$ & $<0.10$ & n.d. \\
\hline 8 & "U Piekarskiego" spring & $9.2-10.3$ & $7.28-7.45$ & $105-111$ & $18-32.4$ & $7.5-12.3$ & $1.3-2.7$ & $287-348$ & $91.2-104.7$ & $19.5-28.5$ & $26.1-39.9$ & $0.02-0.09$ & $4.74-6.3$ \\
\hline $\mathrm{n}=5$ & class III & 9.9 & 7.38 & 109 & 25.7 & 8.86 & 1.83 & 312 & 96.9 & 23.7 & 31.4 & 0.058 & 5.53 \\
\hline 9 & Psary, spring & $8.9-9.6$ & $6.73-7.15$ & $68-84$ & $9.6-16.8$ & $3.4-4.4$ & $1.6-2.5$ & $113-128$ & 95.6-101.5 & $17-22$ & $36.3-52.3$ & $0.06-0.11$ & $8.35-9.8$ \\
\hline $\mathrm{n}=5$ & class III & 9.3 & 6.95 & 70.6 & 12.8 & 3.84 & 1.87 & 121 & 100.1 & 19.3 & 44.2 & 0.082 & 9.3 \\
\hline 10 & Strzemieszyce, spring & $9.0-9.8$ & $7.11-7.33$ & 106-115 & $30-34$ & $16.8-20$ & $1.7-3.3$ & $336-360$ & $91.2-118$ & $45-46$ & $26.6-38.1$ & $0.04-0.06$ & $5.6-6.9$ \\
\hline $\mathrm{n}=2$ & class III & 9.4 & 7.22 & 110 & 32 & 18.4 & 2.5 & 348 & 104.6 & 45.5 & 32.4 & 0.05 & 6.25 \\
\hline 11 & Dąbrowa Górnicza-Zakawie, spring & $7.8-11.7$ & $7.55-7.94$ & $66.2-82$ & $31-33.6$ & 7.8-17.4 & $0.9-2.8$ & $290-317$ & $64.5-76.6$ & $13.9-18,0$ & $10.7-15.1$ & $0.01-0.05$ & $3.4-3.6$ \\
\hline $\mathrm{n}=6$ & class III & 8.8 & 7.62 & 112 & 16.8 & 7.08 & 0.82 & 301 & 77.8 & 21.2 & 38.4 & 0.063 & 5.08 \\
\hline 13 & Rogoźnik, "Pod Górą Buczynowa" spring; & $7.9-9.3$ & 7.33-7.48 & $106-117$ & $14.4-24$ & $6.5-9$ & $0.6-1.1$ & 278-314 & $77-86.3$ & $25-31.5$ & $18.2-28.4$ & $0.04-0.1$ & $5.2-6.44$ \\
\hline $\mathrm{n}=6$ & class II & 8.8 & 7.40 & 109 & 20.25 & 8.0 & 0.82 & 300 & 81.6 & 29.7 & 23.6 & 0.08 & 5.86 \\
\hline & Będzin, "Na Kamionce" spring & $6.5-10$ & $7.58-8.06$ & $74-80$ & $20.8-31$ & $2.2-2.4$ & $0.7-1$ & $244-260$ & $77.5-81.4$ & $5.3-6$ & $4.6-5.8$ & $0.03-0.06$ & $4.7-5.8$ \\
\hline $\mathrm{n}=2$ & class II & 8.2 & 7.82 & 77 & 25.9 & 2.3 & 0.85 & 252 & 79.4 & 5.65 & 5.2 & 0.045 & 5.25 \\
\hline $\begin{array}{c}15 \\
n=1\end{array}$ & $\begin{array}{c}\text { Strzemieszyce, } \\
\text { "Majewskiego" spring }\end{array}$ & 7.1 & 7.12 & 172 & 37.1 & 4.9 & 0.7 & 497 & 148 & 17.5 & 18.6 & 0.05 & 5.9 \\
\hline & The range of variability ${ }^{3}$ & $5.1-13.0$ & $6.50-8.30$ & $66-182$ & $9.6-52.8$ & $2.2-47.2$ & $0.6-10.5$ & $113-529$ & $61.3-201$ & $5.3-88$ & $4.6-73.1$ & $0.02-0.20$ & $3.6-9.8$ \\
\hline & Natural hydrogeochemical background ${ }^{4}$ & $4-20$ & $6.5-9.5$ & $2-200$ & $0.5-30$ & $1-60$ & $0.5-10$ & $60-360$ & $5-60$ & $2-60$ & $0-5$ & $0.01-1.0$ & $1-30$ \\
\hline & Limit values for drinking water ${ }^{5}$ & - & $6.5-9.5$ & & 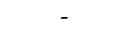 & 200 & - & 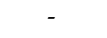 & 250 & 250 & 50 & 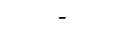 & - \\
\hline
\end{tabular}

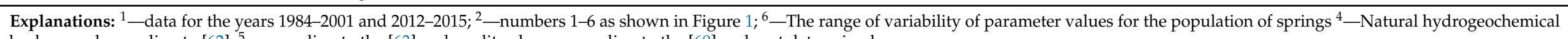
background according to [62]; ${ }^{5}$-according to the [63] and quality class-according to the [60]; n.d. not determined. 
The transformation of the water chemistry of the springs as a result of human pressure exceeding the value of the natural hydrogeochemical background [62] was as follows: EC $200-700 \mu \mathrm{S} \mathrm{cm}^{-1}$ in the waters of eight springs; total hardness $\mathrm{CaCO}_{3}$ $100-400 \mathrm{mg} \mathrm{L}^{-1}$ in the waters of 5 springs; $\mathrm{Mg} 0.5-30 \mathrm{mg} \mathrm{L}^{-1}$ in the waters of 6 springs; $\mathrm{HCO}_{3} 60-360 \mathrm{mg} \mathrm{L}^{-1}$ in the waters of 4 springs; $\mathrm{SO}_{4} 5-60 \mathrm{mg} \mathrm{L}^{-1}$ and $\mathrm{NO}_{3}$ $0-5 \mathrm{mg} \mathrm{L}^{-1}$ in the waters of all springs, $\mathrm{Cl} 2-60 \mathrm{mg} \mathrm{L}^{-1}$ in the waters of the "Długosz 36 " spring. The limit values for drinking water [63] were found to exceed $\mathrm{NO}_{3}$ concentrations (50 mg L ${ }^{-1}$ ) ("Długosza 36", "Pod Morwa", "Psary" springs; 51-73 mg L ${ }^{-1}$ ) and total hardness (60-500 mg CaCO $3 \mathrm{~L}^{-1}$ ) ("Długosza 36", "Brzeziny", "Strzemieszyce”, "Majewskiego Street" springs; 523-650 $\mathrm{mg} \mathrm{L}^{-1}$ ) (Table 2, Tables S1 and S3). The waters of the studied springs usually belong to quality class III (water of satisfactory quality), due to the increased concentrations of $\mathrm{NO}_{3}$ in the water, and only in the case of the "Długosza 36 " spring to quality class IV (Table 2). The increased presence of biogenic compounds in groundwater is common in Poland [64]. Bacteriological hazards disqualify these waters as drinking water, in contrast to water from deep wells (e.g., presence of coliform bacteria in $100 \mathrm{~mL}$ of the sample (5 to over 100), Escherichia coli bacteria in $100 \mathrm{~mL}$ of water (15 to over 100), fecal enterococci in $100 \mathrm{~mL}$ of the water sample (2-42), Clostridium perfingens $1-68)$. The chemistry and quality of groundwater drained by springs are detailed in Piper's diagram (Figure 7) and in Tables S1 and S3.

\section{Conclusions}

1. The article discusses environmental transformations in the area of Wojkowice in southern Poland up to the year 2020. A comprehensive ecological analysis was carried out concerning spatial development, mining activity, hydrogeological conditions and the biotic environment;

2. The results of the research showed that the ground surface in Wojkowice dropped on average by $5 \mathrm{~m}$, from an elevation 260-366 m.a.s.l. to 254-365 m.a.s.l. The largest changes in relief occurred in the northern part of the town and were connected to limestone extraction by the "Saturn" Cement Plant and in the eastern part in the bootleg mining area of the "Uciekaj" Bootleg Mine. The coal extraction in the "Jowisz" Coal Mine caused ground subsidence and the development of post-mining waste tips, mainly in the south-eastern and eastern part of the town. The analysis of the Differential Model (DFM) made it possible to determine changes in elevation reaching $55 \mathrm{~m}$ with extreme values from -29 to $+26 \mathrm{~m}$. In the line of topographic profile, local denivelations were distinguished (the ground surface dropped by $36 \mathrm{~m}$ in the excavation of the limestone quarry of the "Saturn" Cement Plant and over $25 \mathrm{~m}$ in the excavation of bootleg mining of "Uciekaj" Mine) as were local elevations (14-24 m high post-mining waste tips of "Jowisz" Coal Mine);

3. The development of industry in Wojkowice caused the degradation of the natural environment. Contemporary vegetation is completely different from the potential natural vegetation and is an indicator of the complete anthropogenic transformation and the change of the vegetation of the area. Currently, herbaceous communities dominate the vegetation of Wojkowice. The most valuable of these is phytocoenoses types of calcareous, multi-species xerothermic grasslands of the Festuco-Brometea class, the most valuable patches of which developed in the "Żychcice-Saturn" quarry, the post-limestone excavation in the "Saturn" Cement Plant and on the sunny open hills. The largest forest complex is the Town Park and the small ones are characterized by a species composition consistent with the habitat (in the Brynica valley, in the former excavations of the "Uciekaj" Coal Mine and the remains of riparian forests by the Wielonka stream and in the upper course of the Jaworznik stream);

4. The mining activity of the zinc and lead mines of "Orzeł Biały" Mining and Metallurgical Plant and the "Jowisz" hard coal mine resulted in quantitative depletion of groundwater in the Triassic and Carboniferous deposits. The Muschelkalk aquifer was practically drained and lost its functional nature due to the necessity to further 
drain the mine workings of the inactive $\mathrm{Zn}$ and $\mathrm{Pb}$ ore mines. At present, only the Röth aquifer is usable;

5. The intense anthropopressure in Wojkowice, in conditions of a very high degree of groundwater endangering, caused a transformation of the groundwater chemistry. The waters taken from deep wells have increased mineralization, belong to the multiionic types of water, are characterized by relatively high concentrations of $\mathrm{SO}_{4}, \mathrm{NO}_{3}$, $\mathrm{PO}_{4}, \mathrm{Cl}, \mathrm{Mg}, \mathrm{Zn}$, have a general hardness, and require treatment. The water of the "Rozkówka R-1" intake was mainly quality class IV (high concentrations of $\mathrm{NO}_{3}$ and $\mathrm{SO}_{4}$ in the water) and the "Przełajka-3" intake was mainly quality class III, periodically in class IV due to concentrations of $\mathrm{SO}_{4}$. In the waters of the "Rozkówka R-1" well, the concentration of anthropogenic $\mathrm{NO}_{3}$ exceeds the limit values for drinking water. In addition, in the waters of the deep wells, the limit values for drinking water were occasionally exceeded in relation to $\mathrm{SO}_{4}, \mathrm{Mg}$, and total hardness, which is conditioned by the presence of the carbonate rock environment;

6. Water drained from the springs, representing the shallow circulation system, belong mainly to the III class of water quality, and occasionally even to the IV quality class (concentrations of $\mathrm{SO}_{4}$ and $\mathrm{NO}_{3}$ ). The water from springs presents a bacteriological risk. Moreover, the limit values for drinking water exceed $\mathrm{NO}_{3}$ concentrations and total hardness in the waters of several springs;

7. In conclusion, it could be stated that more than a century of industrial activity has profoundly transformed the town's natural environment. Currently, Wojkowice is a small post-mining town which, like hundreds of similar towns in the world, must make a successful economic transformation in order to develop in a modern and environmentally sustainable way. This is a condition of the city's continued existence.

Supplementary Materials: The following are available online at https: / www.mdpi.com/article/ 10.3390/resources10050054/s1, Table S1: Chemistry of the Triassic aquifer in Wojkowice and the surrounding area (06.2016). Table S2A: Chemistry of the water from Triassic aquifer in "Przełajka-3” in Czeladź (No 2228 in MONBADA) and in "Rozkówka R-1” in Będzin (No 2230 in MONBADA) in 2007-2015. Table S2B: Chemistry of the water from Triassic aquifer in "Przełajka-3” in Czeladź (No 2228 in MONBADA) and in "Rozkówka R-1” in Będzin (No 2230 in MONBADA) in 2007-2015. Table S3: Water chemistry of springs of the Triassic aquifer in Wojkowice and the surrounding area (2015.11.06-2019.03.11).

Author Contributions: Conceptualization, J.R.; methodology, J.R., R.Z. and A.Z.; software, R.Z., A.Z.; validation, J.R., O.R., R.Z. and A.Z.; investigation, J.R., O.R., R.Z. and A.Z.; writing-original draft preparation, J.R., O.R., R.Z. and A.Z.; writing-review and editing, J.R., O.R., R.Z. and A.Z.; visualization, R.Z. and A.Z. All authors have read and agreed to the published version of the manuscript.

Funding: This research received no external funding.

Institutional Review Board Statement: Not applicable.

Informed Consent Statement: Not applicable.

Data Availability Statement: Not applicable.

Conflicts of Interest: The authors declare no conflict of interest.

\section{References}

1. Hilson, G. Pollution prevention and cleaner production in the mining industry: An analysis of current issues. J. Clean. Prod. 2000, 8, 119-126. [CrossRef]

2. Frelich, L.E. Terrestrial Ecosystem Impacts of Sulfide Mining: Scope of Issues for the Boundary Waters Canoe Area Wilderness, Minnesota, USA. Formula 2019, 10, 747. [CrossRef]

3. Różkowski, J.; Rahmonov, O.; Szymczyk, A. Environmental Transformations in the Area of the Kuźnica Warężyńska Sand Mine, Southern Poland. Land 2020, 9, 116. [CrossRef]

4. Tarolli, P.; Sofia, G. Human topographic signatures and derived geomorphic processes across landscapes. Geomorphology 2016, 255, 140-161. [CrossRef]

5. Laurence, D. Establishing a sustainable mining operation: An overview. J. Clean. Prod. 2011, 19, 278-284. [CrossRef] 
6. Lei, K.; Pan, H.; Lin, C. A landscape approach towards ecological restoration and sustainable development of mining areas. Ecol. Eng. 2016, 90, 320-325. [CrossRef]

7. Pactwa, K.; Woźniak, J.; Dudek, M. Coal mining waste in Poland in reference to circular economy principles. Fuel 2020, 270, 117493. [CrossRef]

8. Hendrychová, M.; Kabrna, M. An analysis of 200-year-long changes in a landscape affected by large-scale surface coal mining: History, present and future. Appl. Geogr. 2016, 74, 151-159. [CrossRef]

9. Mi, J.; Yang, Y.; Zhang, S.; An, S.; Hou, H.; Hua, Y.; Chen, F. Tracking the Land Use/Land Cover Change in an Area with Underground Mining and Reforestation via Continuous Landsat Classification. Remote Sens. 2019, 11, 1719. [CrossRef]

10. Govorushko, S.M. Mining and Mineral Processing. In Natural Processes and Human Impacts; Springer Science and Business Media LLC: Berlin/Heidelberg, Germany, 2012; pp. 485-511.

11. Goudie, A. The Human Impact on the Natural Environment: Past, Present and Future, 7th ed.; John Wiley \& Sons: Hoboken, NJ, USA, 2018; ISBN 9781405127042.

12. Boengiu, S.; Ionuş, O.; Marinescu, E. Man-made Changes of the Relief Due to the Mining Activities within Husnicioara Open Pit (Mehedinţi County, Romania). Procedia Environ. Sci. 2016, 32, 256-263. [CrossRef]

13. Dulias, R. The Impact of Mining on the Landscape. In A Study of the Upper Silesian Coal Basin in Poland; Environmental Science and Engineering; Springer International Publishing: Cham, Switzerland, 2016; ISBN 978-3-319-29539-8.

14. Ribeiro, J.; Suárez-Ruiz, I.; Ward, C.R.; Flores, D. Petrography and mineralogy of self-burning coal wastes from anthracite mining in the El Bierzo Coalfield (NW Spain). Int. J. Coal Geol. 2016, 154-155, 92-106. [CrossRef]

15. Ribeiro, J.; Suárez-Ruiz, I.; Flores, D. Geochemistry of self-burning coal mining residues from El Bierzo Coalfield (NW Spain): Environmental implications. Int. J. Coal Geol. 2016, 159, 155-168. [CrossRef]

16. Alekseenko, V.A.; Bech, J.; Alekseenko, A.V.; Shvydkaya, N.V.; Roca, N. Environmental impact of disposal of coal mining wastes on soils and plants in Rostov Oblast, Russia. J. Geochem. Explor. 2018, 184, 261-270. [CrossRef]

17. Jaskulski, M.; Nowak, T. Transformations of Landscape Topography of the Bełchatów Coal Mine (Central Poland) and the Surrounding Area Based on DEM Analysis. ISPRS Int. J. Geo-Inf. 2019, 8, 403. [CrossRef]

18. Jancewicz, K.; Traczyk, A.; Migon, P. Landform modifications within an intramontane urban landscape due to industrial activity, Wałbrzych, SW Poland. J. Maps 2020, 1-8. [CrossRef]

19. Zarychta, R.; Zarychta, A.; Bzdęga, K. Progress in the Reconstruction of Terrain Relief before Extraction of Rock Materials-The Case of Liban Quarry, Poland. Remote Sens. 2020, 12, 1548. [CrossRef]

20. Hospers, G.-J. Restructuring Europe's Rustbelt. Intereconomics 2004, 39, 147-156. [CrossRef]

21. Sachsenhofer, R.; Privalov, V.; Panova, O. Basin evolution and coal geology of the Donets Basin (Ukraine, Russia): An overview. Int. J. Coal Geol. 2012, 89, 26-40. [CrossRef]

22. Człowiek, A. Środowisko Geograficzne W Górnoślaskim Okręgu Przemysłowym (Wybrane Zagadnienia); Zieliński, T., Ed.; Instytut Geografii PAN: Warszawa, Poland, 1971.

23. Bartkowski, T. Zastosowania Geografii Fizycznej; PWN: Warsaw, Poland, 1992

24. Fagiewicz, K. Obszary przekształcone w wyniku działalności górniczej w strukturze przestrzennej miast i gmin województwa śląskiego oraz główne problemy ich zagospodarowania. Probl. Ekol. Kraj. 2009, 24, 25-35.

25. Rayfield, B.; Anand, M.; Laurence, S. Assessing Simple Versus Complex Restoration Strategies for Industrially Disturbed Forests. Restor. Ecol. 2005, 13, 639-650. [CrossRef]

26. Grodzińska, K.; Korzeniak, U.; Szarek-Łukaszewska, G.; Godzik, B. Colonization of zinc mine spoils in southern Polandpreliminary studies on vegetation, seed rain and seed bank. Fragm. Florist. Geobot. 2000, 45, 123-145.

27. Anawar, H.M.; Canha, N.; Santa-Regina, I.; Freitas, M.C. Adaptation, tolerance, and evolution of plant species in a pyrite mine in response to contamination level and properties of mine tailings: Sustainable rehabilitation. J. Soils Sediments 2013, 13, 730-741. [CrossRef]

28. Bradshaw, A. The use of natural processes in reclamation-Advantages and difficulties. Landsc. Urban. Plan. 2000, 51, 89-100. [CrossRef]

29. Pyšek, A.; Pyšek, P.; Hajek, M.; Wild, J.; Jarošík, V. Diversity of native and alien plant species on rubbish dumps: Effects of dump age, environmental factors and toxicity. Divers. Distrib. 2003, 9, 177-189. [CrossRef]

30. Prach, K.; Lencová, K.; Řehounková, K.; Dvořáková, H.; Jírová, A.; Konvalinková, P.; Mudrák, O.; Novák, J.; Trnková, R. Spontaneous vegetation succession at different central European mining sites: A comparison across seres. Environ. Sci. Pollut. Res. 2013, 20, 7680-7685. [CrossRef]

31. Oleś, W.; Rahmonov, O.; Rzetala, M.; Pytel, S.; Malik, I. The ways of industrial wastelands management in the Upper Silesian Region. Ekológia 2004, 23, 244-251.

32. Kodir, A.; Hartono, D.M.; Haeruman, H.; Mansur, I. Integrated post mining landscape for sustainable land use: A case study in South Sumatera, Indonesia. Sustain. Environ. Res. 2017, 27, 203-213. [CrossRef]

33. Abramowicz, A.; Rahmonov, O.; Chybiorz, R. Environmental Management and Landscape Transformation on Self-Heating Coal-Waste Dumps in the Upper Silesian Coal Basin. Land 2020, 10, 23. [CrossRef]

34. Rahmonov, O.; Skreczko, S.; Rahmonov, M. Changes in Soil Features and Phytomass during Vegetation Succession in Sandy Areas. Land 2021, 10, 265. [CrossRef] 
35. Woźniak, G. Diversity of Vegetation on Coalmine Heaps of the Upper Silesia (Poland); W. Szafer Institute of Botany, Polish Academy of Sciences: Kraków, Poland, 2010.

36. Rahmonov, O.; Krzysztofik, R.; Środek, D.; Smolarek-Lach, J. Vegetation- and Environmental Changes on Non-Reclaimed Spoil Heaps in Southern Poland. Biology 2020, 9, 164. [CrossRef]

37. Różkowski, A.; Chmura, A.; Siemiński, A. (Eds.) Usable Ground Waters in the Upper Silesian Coal Basin and Its Margin; Pracer Państwowego Instytutu Geologicznego: Warsaw, Poland, 1997; Available online: https:/ / searchworks.stanford.edu/view/3962 399 (accessed on 16 January 2021).

38. Wagner, J.; Chmura, A.; Siemiński, A. Hydrogeological Map of Poland; 1:50,000, sheet Wojkowice (911); PIG: Warsaw, Poland, 1997; ISSN 0866-9465.

39. Europe. Carlos Efraín Porto Tapiquén. Orogénesis Soluciones Geográficas. Porlamar, Venezuela Based on Shapes from Enviromental Systems Research Institute (ESRI). Free Distribuition. Available online: http:/ / tapiquen-sig.jimdo.com (accessed on 16 January 2021).

40. Orthophotomap. Available online: https:// mapy.geoportal.gov.pl/imap/Imgp_2.html?locale=pl\&gui=new\&sessionID=5428962 (accessed on 16 January 2021).

41. Przemsza-Zieliński, J. (Ed.) Wojkowice Wczoraj i Dziś. Szkice Monograficzne Wydane z Okazji XXXV-Lecia Istnienia Miasta 1962-1997; Sosnowiecka Oficyna Wydawniczo-Autorska; “Sowa-Press” Zakład Poligraficzno-Wydawniczy Plik: Piekary Śląskie, Poland, 1997.

42. Jarmołowicz, W.; Piątek, D. Polska Transformacja Gospodarcza. Przesłanki-Przebieg-Rezultaty. In W Poszukiwaniu Nowego Ładu Ekonomicznego; Owsiak, S., Pollok, A., Eds.; Polskie Wydawnictwo Ekonomiczne: Warszawa, Poland, 2013 ; pp. 71-89.

43. European Union. Copernicus Land Monitoring Service 2018; European Environment Agency (EEA): Copenhagen, Denmark, 2021.

44. Ministerstwo Robót Publicznych i Ministerstwo Przemysłu i Handlu, Kierownictwo Pomiarów Zagłębia Dąbrowskiego. Mapa Zagłębie Dąbrowskie; 1:10,000, Sheet Rogoźnik; Wykonano według pomiarów z r. 1925-Druk Wojskowego Instytutu Geograficznego w Warszawie: Warsaw, Poland, 1929.

45. Ministerstwo Robót Publicznych i Ministerstwo Przemysłu i Handlu, Kierownictwo Pomiarów Zagłębia Dąbrowskiego. Mapa Zagłębie Dąbrowskie 1:10,000, Sheet Strzyżowice; Wykonano według pomiarów z r. 1925-Druk Wojskowego Instytutu Geograficznego w Warszawie: Warsaw, Poland, 1929.

46. Ministerstwo Robót Publicznych i Ministerstwo Przemysłu i Handlu, Kierownictwo Pomiarów Zagłębia Dąbrowskiego. Mapa Zagłębie Dą̧rowskie 1:10,000, Sheet Kol. kop. Jowisz; Wykonano według pomiarów z r. 1925-Druk Wojskowego Instytutu Geograficznego w Warszawie: Warsaw, Poland, 1929.

47. Ministerstwo Robót Publicznych i Ministerstwo Przemysłu i Handlu, Kierownictwo Pomiarów Zagłębia Dąbrowskiego. Mapa Zagłębie Dąbrowskie 1:10,000, Sheet Grodziec; Wykonano według pomiarów z r. 1925-Druk Wojskowego Instytutu Geograficznego w Warszawie: Warsaw, Poland, 1929.

48. Goovaerts, P. Geostatistics for Natural Resources Evaluation; Oxford Univ. Press: New York, NY, USA, 1997.

49. Bzdega, K.; Zarychta, A.; Urbisz, A.; Szporak-Wasilewska, S.; Ludynia, M.; Fojcik, B.; Tokarska-Guzik, B. Geostatistical models with the use of hyperspectral data and seasonal variation-A new approach for evaluating the risk posed by invasive plants. Ecol. Indic. 2021, 121, 107204. [CrossRef]

50. Zarzyski, K.; Trzcińska-Tacik, H.; Różański, W.; Szelag, Z.; Wołek, J.; Korzeniak, U. Ecological Indicator Values of Vascular Plants of Poland; W. Szafer Institute of Botany, PAN: Kraków, Poland, 2002.

51. Matuszkiewicz, J.M. Potential Natural Vegetation of Poland; IGSO PAS: Warsaw, Poland, 2008.

52. Mirek, Z.; Piekoś-Mirkowa, H.; Zajac, A.; Zajac, M. Flowering Plants and Pteridophytes of Poland. A Checklist. In Biodiversity of Poland; W. Szafer Institute of Botany, PAN: Kraków, Poland, 2002; Volume 1.

53. Różkowski, J.; Jóźwiak, K.; Sadowski, S.; Wesołowski, S. Water quality of the Triassic aquifer in the area of groundwater flow to the designed well in Wojkowice (MGB Bytom). Przeglad. Geol. 2017, 65, 1377-1382.

54. Rahmonov, O.; Snytko, V.A.; Szczypek, T. Influence of melioration in natural ecological processes of a small river valley (Poland). Geogr. Nat. Resour. 2016, 37, 379-384. [CrossRef]

55. Rahmonov, O.; Snytko, V.A.; Szczypek, T.; Parusel, T. Vegetation development on post-industrial territories of the Silesian Upland (Southern Poland). Geogr. Nat. Resour. 2013, 34, 96-103. [CrossRef]

56. Piekarska-Stachowiak, A.; Szary, M.; Ziemer, B.; Besenyei, L.; Woźniak, G. An application of the plant functional group concept to restoration practice on coal mine spoil heaps. Ecol. Res. 2014, 29, 843-853. [CrossRef]

57. Baranowski, H. Bytom Region of Ore Deposits. In Hydrogeological Conditions of Zinc and Lead Ore Deposits in the Silesia-Krakow Region; Różkowski, A., Wilk, Z., Eds.; Wyd. Geologiczne: Warsaw, Poland, 1980; pp. 113-140.

58. Kropka, J.; Respondek, J. Hydrogeological and mining problems of the central dewatering system in mined-out ore workings in the Bytom Trough (Southern Poland). Przeglad. Geol. 2000, 48, 727-735.

59. Kropka, J.; Wróbel, J. The background of changes in water supply to the Bolko Central Pumping Station in Bytom. Przeglad. Górniczy 2018, 74, 1-8.

60. Regulation of the Minister of Maritime and Inland Navigation of 11 October on the criteria and method of assesing the status of groundwater bodies. Journal of Laws of the Republic of Poland 2019, item 2148. pp. 1-9. Available online: https: / / isap.sejm.gov.pl/isap.nsf/DocDetails.xsp?id=WDU20190002149 (accessed on 16 January 2021). 
61. Rahmonov, O.; Różkowski, J.; Różkowski, K. Heavy metals in the unsaturated and saturated zone of the Upper Jurassic carbonate massif in the vicinity of Kraków. J. Elementol. 2012, 20, 395-406. [CrossRef]

62. Różkowski, J.; Różkowski, K.; Rahmonov, O.; Rubin, H. Nitrates and phosphates in cave waters of Kraków-Częstochowa Upland, southern Poland. Environ. Sci. Pollut. Res. 2017, 24, 25870-25880. [CrossRef]

63. Witczak, S.; Kania, J.; Kmiecik, E. Catalog of Selected Physical and Chemical Indicators of Groundwater Pollution and Methods of Their Determination; Inspekcja Ochrony Środowiska: Warsaw, Poland, 2013.

64. Regulation of the Minister of Health of 7 December 2017 on the quality of water intended for human consumption. Journal of Laws of the Republic of Poland 2017, item 2294. pp. 1-42. Available online: http://isap.sejm.gov.pl/isap.nsf/DocDetails.xsp?id= WDU20170002294 (accessed on 16 January 2021). 